\title{
Kritijhe Dierteljahresid̨rift
}

\section{fiit \\ Gejebgebung uno Reゆ̨tswifjenjळant}

herausgegeben von

DrDr. K. v. Birtmener, A. Dụroff, k. v. Srant, w. Kiił \&. wenget, profefforen dex Mündener Juriftenfakultät.

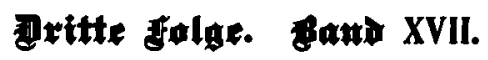

(Der garzen Solge Band LIII).

1916.

mänden, Berlin und Seipjig.

J. Sdweizer Derlag (Uathur Sellier). 
